\title{
Cladribine vs other drugs in MS
}

\section{Merging randomized trial with real-life data}

\begin{abstract}
Alessio Signori, PhD, Francesco Saccà, MD, Roberta Lanzillo, MD, PhD, Giorgia Teresa Maniscalco, MD, Elisabetta Signoriello, MD, PhD, Anna Maria Repice, MD, Pietro Annovazzi, MD, Damiano Baroncini, MD, Marinella Clerico, MD, PhD, Eleonora Binello, MD, Raffaella Cerqua, MD, Giorgia Mataluni, MD, PhD, Paola Perini, MD, PhD, Simona Bonavita, MD, Luigi Lavorgna, MD, PhD, Ignazio Roberto Zarbo, MD, PhD, Alice Laroni, MD, PhD, Lorena Pareja-Gutierrez, MD, Sara La Gioia, MD, Barbara Frigeni, MD,

Valeria Barcella, MD, Jessica Frau, MD, Eleonora Cocco, MD, Giuseppe Fenu, MD, PhD, Valentina Torri Clerici, MD, Arianna Sartori, MD, Sarah Rasia, MD, Cinzia Cordioli, MD, Maria Laura Stromillo, MD, PhD, Alessia Di Sapio, MD, Simona Pontecorvo, MD, PhD, Roberta Grasso, MD, Stefania Barone, MD, Caterina Barrilà, MD, Cinzia Valeria Russo, MD, Sabrina Esposito, MD, Domenico Ippolito, MD, Doriana Landi, MD, PhD, Andrea Visconti, MD, and Maria Pia Sormani, PhD
\end{abstract}

Neurol Neuroimmunol Neuroinflamm 2020;7:e878. doi:10.1212/NXI.0000000000000878

\section{Abstract}

\section{Objective}

Cladribine tablets were tested against placebo in randomized controlled trials (RCTs). In this study, the effectiveness of cladribine vs other approved drugs in patients with relapsingremitting MS (RRMS) was compared by matching RCT to observational data.

\section{Methods}

Data from the pivotal trial assessing cladribine tablets vs placebo (CLARITY) were propensity score matched to data from the Italian multicenter database i-MuST. This database included 3,150 patients diagnosed between 2010 and 2018 at 24 Italian MS centers who started a diseasemodifying drug. The annualized relapse rate (ARR) over 2 years from treatment start and the 24-week confirmed disability progression were compared between patients treated with cladribine and other approved drugs (interferon, glatiramer acetate, fingolimod, natalizumab, and dimethyl fumarate), with comparisons with placebo as a reference. Treatment effects were estimated by the inverse probability weighting negative binomial regression model for ARR and Cox model for disability progression. The treatment effect has also been evaluated according to baseline disease activity.

\section{Results}

All weighted baseline characteristics were well balanced between groups. All drugs tested had an effect vs placebo close to that detected in the RCT. Patients treated with cladribine had a significantly lower ARR compared with interferon (relapse ratio $[\mathrm{RR}]=0.48 ; p<0.001$ ), glatiramer acetate $(\mathrm{RR}=0.49 ; p<0.001)$, and dimethyl fumarate $(\mathrm{RR}=0.6 ; p=0.001)$; a similar ARR to that with fingolimod $(\mathrm{RR}=0.74 ; p=0.24)$; and a significantly higher ARR than

\author{
Correspondence \\ Dr. Sormani \\ mariapia.sormani@unige.it
}

MORE ONLINE

$\rightarrow$ Class of Evidence

Criteria for rating

therapeutic and diagnostic studies

NPub.org/coe

From the Department of Health Sciences (A. Signori, M.P.S.), Section of Biostatistics, University of Genoa; Department of Neurosciences (F.S., R.L., C.V.R.), Reproductive Sciences and Odontostomatology, Multiple Sclerosis Center, Federico II University, Naples; Neurological Clinic and Multiple Sclerosis Center of "AORN A.Cardarelli" (G.T.M.), Naples; Centro di Sclerosi Multipla (E.S.), II Clinica Neurologica, Università della Campania "Luigi Vanvitelli," Napoli; 2nd Neurology Unit and CRRSM (Regional Referral Multiple Sclerosis Center) (A.M.R.), Careggi University Hospital, University of Florence; Multiple Sclerosis Study Center (P.A., D.B.), ASST Valle Olona, PO di Gallarate (VA); Clinical and Biological Sciences Department (M.C.), Neurology Unit, University of Torino, San Luigi Gonzaga Hospital, Orbassano; Centro SM (E.B.), Dipartimento di Neuroscienze, Ospedale Universitario Città della Salute e della Scienza di Torino; Neurological Clinic (R.C.), Department of Experimental and Clinical Medicine, Marche Polytechnic University, Ancona; Policlinic Tor Vergata (G.M., D.L.), Rome; The Multiple Sclerosis Center of the Veneto Region (P.P.), Department of Neurosciences, University of Padua; Department of Medical, Surgical, Neurological, Metabolic and Aging Sciences (S. Bonavita, L.L., S.E., D.I.), University of Campania Luigi Vanvitelli, Naples; Department of Clinical and Experimental Medicine (I.R.Z.), University of Sassari; Department Neuroscience, Rehabilitation, Ophthalmology, Genetics, Maternal and Child Health (A.L.), Center of Excellence for Biomedical Research (CEBR), University of Genova; Neuroimmunology and Neuromuscular Diseases Unit (L.P.-G., V.T.C.), IRCCS Foundation Carlo Besta Neurological Institute, Milan; Centro Sclerosi Multipla ASST Papa Giovanni XXIII di Bergamo (S.L.G., B.F., V.B.); Department of Medical Science and Public Health (..F., E.C., G.F.), University of Cagliari; Neurology Clinic (A. Sartori), Department of Medical, Surgical, and Health Sciences, University of Trieste; Multiple Sclerosis Center (S.R., C.C.), ASST Spedali Civili, PO di Montichiari (BS); Department of Medicine, Surgery and Neuroscience (M.L.S.), University of Siena; 2nd Neurology Unit and CReSM (Regional Referral Multiple Sclerosis Center) (A.D.S.), AOU San Luigi Gonzaga, Orbassano, Torino; Regina Montis Regalis Hospital (A.D.S.), Mondovi; Department of Neurology and Psychiatry (S.P.), Sapienza University, Rome; Neurologia Universitaria OORR (R.G.), Foggia; Institute of Neurology (S. Barone), University Magna Graecia of Catanzaro; Department of Neurology (C.B.), Valduce Hospital, Como; Merck Serono S.p.A. (A.V.), Rome; and IRCCS Ospedale Policlinico San Martino (A.L., M.P.S.), Genova, Italy.

Go to Neurology.org/NN for full disclosures. Funding information is provided at the end of the article.

The Article Processing Charge was funded by Merck.

This is an open access article distributed under the terms of the Creative Commons Attribution-NonCommercial-NoDerivatives License 4.0 (CC BY-NC-ND), which permits downloading and sharing the work provided it is properly cited. The work cannot be changed in any way or used commercially without permission from the journal. 


\section{Glossary}

ARR = annualized relapse rate; $\mathbf{D M D}=$ disease-modifying drug; $\mathbf{D M F}=$ dimethyl fumarate; EDSS $=$ Expanded Disability Status Scale; FS = functional system; FTY = fingolimod; GA = glatiramer acetate; HAD = high disease activity; HR = hazard ratio; IFN = interferon; IPW = inverse probability weighting; NMA = network meta-analysis; NTZ = natalizumab; PS = propensity score; $\mathbf{R R M S}=$ relapsing-remitting MS; SC = subcutaneous; TERI = teriflunomide.

natalizumab $(\mathrm{RR}=2.13 ; p=0.014)$, confirming results obtained by indirect treatment comparisons from RCTs (network metaanalyses). The relative effect of cladribine tablets $10 \mathrm{mg}$ (cumulative dose $3.5 \mathrm{mg} / \mathrm{kg}$ over 2 years) was higher in patients with high disease activity vs all treatments except fingolimod and natalizumab. Effects on disability progression were largely nonsignificant, probably due to lack of power for such analysis.

\section{Conclusion}

In patients with RRMS, cladribine tablets showed lower ARR compared with matched patients who started interferon, glatiramer acetate, or dimethyl fumarate; was similar to fingolimod; and was higher than natalizumab. The beneficial effect of cladribine tablets was generally amplified in the subgroup of patients with high disease activity.

\section{Classification of evidence}

This study provides Class III evidence that for patients with RRMS, cladribine-treated patients had lower ARR compared with interferon, glatiramer acetate, or dimethyl fumarate; similar ARR compared with fingolimod; and higher ARR compared with natalizumab.

Relapsing-remitting MS (RRMS) is characterized by periodic exacerbations of disease symptoms followed by periods of remission, in which symptoms are either partially or completely absent. Disease-modifying drugs (DMDs) are able to decrease the frequency and duration of relapses and sometimes to slow the progression of the disease. ${ }^{1}$

Cladribine tablet is hypothesized as an immune reconstitution therapy that targets specific subsets of the adaptive immune system. ${ }^{2}$ As demonstrated in the CLARITY phase 3 randomized controlled study, a short-course treatment $(8-20 \mathrm{~d} / \mathrm{y})$ with cladribine tablets provided a sustained treatment benefit for patients with RRMS. ${ }^{3}$ In particular, the 2 tested doses of cladribine $(3.5$ and $5.25 \mathrm{mg} / \mathrm{kg}[3.5 \mathrm{mg} / \mathrm{kg}$ is the approved dose]) were superior to placebo in suppressing relapse activity and increasing the probability of remaining relapse-free. In the CLARITY extension, the clinical benefits of 2 years of treatment with cladribine tablets were shown to be sustained, without the need for retreatment. ${ }^{4}$

In this study, we conducted a propensity score (PS)-matched analysis of observational data from the CLARITY trial data set and the Italian multicenter database i-MuST, which includes 3,150 patients diagnosed between 2010 and 2018 at 24 Italian MS centers who started a DMD.

We aim to fill in the gap in the current RRMS treatment landscape, as no direct head-to-head comparisons of cladribine with other common immunotherapies have yet been conducted. In particular, we try to define the role of cladribine tablets in the context of the other available therapies for MS by an individual-level comparative efficacy analysis of cladribine tablets vs other common immunotherapies, such as interferon beta (IFN $\beta$-1a and $\beta$-1b), glatiramer acetate (GA), fingolimod (FTY), natalizumab (NTZ), dimethyl fumarate (DMF), and teriflunomide (TERI), as first-line therapies for RRMS in Italy.

\section{Methods}

\section{Patients}

This is an observational retrospective study merging 2 data sets. Details on the study design of the CLARITY data set can be found in the article reporting the clinical trial results, ${ }^{3}$ and details about the $\mathrm{i}-\mathrm{MuST}$ database collection can be found in previous publications. ${ }^{5}$ This study takes advantage of the availability of the placebo arm of the CLARITY study, thus providing a reference to which each treatment can be compared.

Briefly, in the CLARITY study 1,326 patients were randomly assigned in a 1:1:1 ratio to receive 1 of 2 doses of cladribine tablets (either $3.5 \mathrm{mg}$ or $5.25 \mathrm{mg} / \mathrm{kg}$ of body weight) or placebo. Patients randomized to the $3.5 \mathrm{mg} / \mathrm{kg}$ cumulative dose received a first treatment course at weeks 1 and 5 of the first year and a second treatment course at weeks 1 and 5 of the second year. Patients were eligible if they had received a diagnosis of RRMS (according to the McDonald criteria, 20016), had lesions consistent with MS on MRI, had had at least 1 relapse within 12 months before study entry, and had a score of $\leq 5.5$ on the Expanded Disability Status Scale (EDSS).

The i-MuST data set is a multicenter, retrospective database, involving 24 Italian MS centers. The data set used for this analysis included 3,006 patients with RRMS. From these, 
patients satisfying the same inclusion/exclusion criteria as CLARITY were extracted. Inclusion criteria were age over 16 years, diagnosis of RRMS (2001 International Panel Diagnostic Criteria and the 2010 revision $^{6,7}$ ), and initiating a DMD between January 2010 and June 2017. There were no exclusion criteria. The EDSS score ${ }^{8}$ was collected for all patients at therapy start; at therapy switch (if any); every 6-12 months, depending on the center; and at the last follow-up.

Only treatment-naive patients were selected in the CLARITY data set because all the patients enrolled in i-MuST were at their first therapy. As a consequence, the study population was defined as all enrolled patients in CLARITY who did not receive any prior DMD and all the patients enrolled in i-MuST who satisfied the inclusion criteria of CLARITY.

The following variables were common to the 2 data sets and were merged: age at treatment start, disease duration since onset, baseline EDSS score, presence of gadolinium-enhancing (active) lesions at baseline, sex, relapses in the previous year, first therapy, and date of first therapy start. First relapse, time to first relapse, time to a progression event confirmed at 3 months, and time to a progression event confirmed at 6 months were also extracted from CLARITY and calculated in the i-MuST data set.

The study population was split into the following treatment groups: placebo, cladribine $3.5 \mathrm{mg} / \mathrm{kg}$, cladribine $5.25 \mathrm{mg} / \mathrm{kg}$, IFN $\beta$-1a (subcutaneous [SC]), IFN-1a (SC), IFN $\beta-1 b$, GA, FTY, NTZ, DMF, and TERI. For treatment comparisons, the IFNs were merged in a single IFN group and the 2 cladribine tablets arms in a single cladribine-treated group. Therefore, unless differently specified, the term IFN indicates the 3 IFNs pooled together, and the term cladribine tablets indicates the 2 cladribine arms pooled together.

\section{Standard protocol approvals, registrations, and patient consents}

The study was approved by the Ligurian Region ethical committee (258REG2016). All the centers involved in the study asked for written permission of the use of anonymized personal clinical data for research purposes, and written informed consent was obtained from all study patients included in this study. CLARITY registration—ClinicalTrials.gov number NCT00213135.

\section{Outcomes}

The primary end point for the Class III comparative effectiveness analysis was annualized relapse rate (ARR) over 2 years. The secondary end point was time to onset of 24-week sustained disability progression over 2 years. Patients in i-MuST were censored at their treatment switch or at year 2, whichever happened first.

Definition of relapses in i-MuST followed clinical trial criteria: change in the EDSS score, with an increase of $\geq 0.5$ points on the total score, or an increase of 1 point on 2 functional systems (FSs) or 2 points on $1 \mathrm{FS}$, excluding changes involving bowel/ bladder or cerebral FS. In CLARITY, the definition of relapses closest to those defined in i-MuST was identified to be that of "qualifying relapses," and this variable was used for the analysis.

The ARR for each treatment group was calculated as the total number of relapses experienced in the group divided by the total number of patient-years on study.

The time to onset of 24-week confirmed disability progression is defined as the time from baseline to the first disability progression that is confirmed at the next visit $\geq 24$ weeks after the initial disability progression. Disability progression was defined by 1 of the following: an EDSS score increase of $\geq 1.5$ points from a baseline EDSS score of 0 that is sustained for $\geq 12$ weeks and an EDSS score increase of $\geq 1.0$ point from a baseline EDSS score of 1.0-5.5 (inclusive) for $\geq 24$ weeks.

The date of the initial EDSS assessment at which the minimum increase in the EDSS score is met was the date of onset of the progression. The progression was defined as confirmed when this minimum EDSS change was present on the next study visit occurring after 24 weeks or longer from the onset of the progression. EDSS assessments $\leq 30$ days after a protocol-defined relapse were not used for confirmation of disability progression. If a patient met the defined criteria of confirmed progression and was also having a relapse, the patient was required to meet the defined minimum criteria at the subsequent visit.

Patients without a confirmed progression based on the above rules were censored. The censor date was the date of last EDSS assessment in the study. Patients who withdrew from the study after the baseline visit but before the first clinical evaluation scheduled visit were censored at baseline.

\section{Statistical methods}

Baseline was defined for the i-MuST database as the start of therapy date and for the CLARITY database as the randomization date. Baseline disease and demographic characteristics were summarized by group and overall before any adjustment, using descriptive statistics, and were compared between treatment groups using the standardized mean difference as calculated according to Cohen $\mathrm{d}$ effect size. A Cohen d effect size $>0.1$ denotes meaningful imbalance in the baseline covariates. ${ }^{9-14}$

To mitigate the baseline differences between compared groups, the inverse probability weighting (IPW) approach based on PS was used. The weights correspond to the inverse of the conditional PS of receiving the treatment. The PS was calculated by modeling on the baseline characteristics the probability of receiving each treatment vs another one by a logistic regression model applied to each treatment group in the i-MuST study vs the overall CLARITY study population (since the assignment to cladribine tablets or placebo was randomized). The logistic regression model had treatment group as the dependent variable (placebo/cladribine tablets vs other drug) and the following baseline variables as independent covariates: age, 
disease duration since onset, baseline EDSS score, sex, and relapses in the previous year.

We used stabilized trimmed weights (weights that exceeded a specified threshold are each set to that threshold ${ }^{15}$ ) to mitigate the impact of extremely higher or lower weights on the variability of the estimated treatment effect. ${ }^{15}$ The threshold was based on the quantiles of the distribution of the weights (1st to 5th and 95th to 99th percentiles). ${ }^{15,16}$ For each treatment pair, we choose to trim the weights at the percentile giving the highest reduction of standardized Cohen d differences.

An IPW negative binomial regression model was used to assess differences between treatments on relapse rate over 2 years. The relapse count was used as a dependent variable, the treatment group as an independent variable, and the log of follow-up duration as an offset variable.

The semiparametric IPW Cox regression model was used to assess treatment effect differences on time to disability progression. Cumulative probability to be progressionfree during follow-up was calculated and graphically displayed by mean of Kaplan-Meier survival curves. The estimates of treatment effect were expressed as hazard ratios (HRs) and reported with $95 \%$ CIs and $p$ values. Stata (v.14; StataCorp., College Station, TX) was used for the computation.

\section{Subgroup analyses}

A subgroup analysis assessed the relative treatment effect of each drug vs cladribine tablets in subgroups of patients defined according baseline disease activity. The definition of patients with high disease activity (HDA) at baseline was the one used in a previous article, ${ }^{4}$ as patients with $\geq 2$ relapses during the year before study entry, whether on DMD. The definition including patients with previous relapses while on treatment was not applied here because only naive patients were included in the analyzed cohorts.

All the analyses run on the overall population were rerun on subgroups of patients with and without HDA at baseline. The significance of the difference in treatment effects between subgroups was assesses by interaction tests. The results were displayed by forest plots.

\section{Sensitivity analyses}

The following sensitivity analyses were run: (1) analyses with a PS and IPW calculated including baseline MRI information, run on a reduced sample; (2) analyses including patients treated with cladribine tablets $3.5 \mathrm{mg} / \mathrm{kg}$ only; (3) analyses adjusted by a 1:1 PS matching and a variable ratio $\leq 3: 1 \mathrm{PS}$ matching; and (4) analysis contrasting cladribine tablets vs each IFN separately.

\section{Data availability}

CLARITY and i-MuST data would be available on reasonable request.

\section{Results}

\section{Descriptive analysis}

A total of 2,204 patients from i-MuST and 945 patients from CLARITY were included in the final analysis. Supplementary figure e-1 (links.lww.com/NXI/A298) presents the flowchart for selecting patients from the i-MuST and CLARITY data sets.

In the i-MuST data set, a total of 1,168 patients were treated with IFN, 402 with GA, 113 with FTY, 149 with NTZ, 295 with DMF, and 77 with TERI. In the CLARITY data set, 305 were in the placebo arm, 322 received the cladribine $3.5 \mathrm{mg} /$ $\mathrm{kg}$ dose, and 318 received the cladribine $5.25 \mathrm{mg} / \mathrm{kg}$ dose.

The unweighted characteristics of all patients included in the analysis, according to the treatment group in the i-MuST database and in CLARITY, are presented in table e-1 (links.lww. com/NXI/A298). In CLARITY, patients were randomized among treatment arms; therefore, data are presented here for the overall CLARITY study, according to the IPW approach used. The baseline characteristics detailed for each treatment arm are reported in table e- 2 .

Patients included in i-MuST were generally younger (excluding patients treated with GA, who were in the same age range, and patients treated with TERI, who were older) than patients included in CLARITY. EDSS levels were generally well balanced (small standardized differences in range of $0.20-0.37$ ) between CLARITY patients and patients treated with FTY, NTZ, and TERI, whereas patients treated with IFN, GA, and DMF had lower EDSS baseline scores. Disease duration was generally lower in i-MuST compared with CLARITY patients with mild to moderate differences. Patients enrolled in i-MuST (especially FTY, NTZ, and DMF) showed a higher frequency of active lesions at baseline compared with trial data. Follow-up duration was lower in i-MuST for patients treated with FTY, DMF, and TERI. The mean time between visits with the EDSS was 157 days with a median of 109 days. Baseline characteristics for each treatment and for CLARITY study after IPW are presented in table 1 . The 3 arms of CLARITY are shown separately and compared with each treatment in tables e-3 to e-8 (links.lww.com/NXI/A298).

The weighted characteristics were well balanced between each treatment group from the i-MuST and CLARITY data sets. A residual unbalance persisted for the EDSS in the IFN and GA arms (with standardized difference in range of $0.25-0.34$ ).

\section{Comparative effectiveness analyses}

\section{Annualized relapse rate}

The IPW-adjusted ARR for each treatment arm is reported in table 2. Treatment with cladribine tablets was associated with a statistically significant reduction in ARR of 52\% vs IFN, $51 \%$ vs GA, and $40 \%$ vs DMF. The reduction of ARR vs FTY was not statistically significant $(p=0.24)$; NTZ was superior to cladribine tablets, and the ARR ratio of cladribine vs NTZ was 
Table 1 Inverse probability-weighted demographic and clinical characteristics Panel A: IFN, GA, and FTY vs CLARITY study

\begin{tabular}{|c|c|c|c|c|c|c|c|c|c|}
\hline & $\begin{array}{l}\text { CLARITY } \\
(n=945)\end{array}$ & $\begin{array}{l}\text { IFN }(n= \\
1,168)\end{array}$ & $\begin{array}{l}\text { Standardized mean } \\
\text { difference IFN vs CLARITY }\end{array}$ & $\begin{array}{l}\text { CLARITY } \\
(n=945)\end{array}$ & $\mathrm{GA}(n=402)$ & $\begin{array}{l}\text { Standardized mean } \\
\text { difference GA vs CLARITY }\end{array}$ & $\begin{array}{l}\text { CLARITY } \\
(\mathrm{n}=945)\end{array}$ & $\operatorname{FTY}(n=113)$ & $\begin{array}{l}\text { Standardized mean } \\
\text { difference FTY vs CLARITY }\end{array}$ \\
\hline Age, y, mean (SD) & $37.3(10.1)$ & $36.6(10.7)$ & 0.071 & $38.8(10.2)$ & $39.5(11.8)$ & 0.07 & $38.4(10.3)$ & $38.1(11.6)$ & 0.025 \\
\hline Females, n (\%) & $629(66.5)$ & $768(65.7)$ & 0.018 & $629(66.5)$ & $269(66.9)$ & 0.008 & $614(65)$ & $69(61.1)$ & 0.08 \\
\hline $\begin{array}{l}\text { EDSS score, mean } \\
\text { (SD); median (IQR) }\end{array}$ & $\begin{array}{l}2.46(1.25) ; 2 \\
(1.5-3.5)\end{array}$ & $\begin{array}{l}2.11(1.17) ; 2 \\
(1-3)\end{array}$ & 0.29 & $\begin{array}{l}2.71(1.28) \\
2.5(2-3.5)\end{array}$ & $\begin{array}{l}2.28(1.32) ; 2 \\
(1-3)\end{array}$ & 0.33 & $\begin{array}{l}2.86(1.28) \\
2.5(2-4)\end{array}$ & $\begin{array}{l}2.81(1.23) \\
2.5(2-3.5)\end{array}$ & 0.04 \\
\hline $\begin{array}{l}\text { Disease duration, } \\
\text { mean } \\
\text { (SD); median (IQR) }\end{array}$ & $\begin{array}{l}2.46(4.45) \\
0.52(0.2-2.6)\end{array}$ & $\begin{array}{l}2.75(4.68) ; \\
0.7(0.2-2.9)\end{array}$ & 0.062 & $\begin{array}{l}3.38(5.05) \\
1.2(0.3-4.6)\end{array}$ & $\begin{array}{l}3.10(5.57) ; \\
1.00(0.17-3)\end{array}$ & 0.052 & $\begin{array}{l}4.08(5.36) ; \\
1.95(0.5-5.8)\end{array}$ & $\begin{array}{l}3.90(6.11) ; \\
1.79(0.3-5.6)\end{array}$ & 0.03 \\
\hline $\begin{array}{l}\text { ARR in previous } \\
\text { year, } \\
\text { mean (SD) }\end{array}$ & $1.32(0.56)$ & $1.33(0.58)$ & 0.013 & $1.33(0.58)$ & $1.32(0.56)$ & 0.024 & $1.35(0.6)$ & $1.36(0.57)$ & 0.01 \\
\hline Active lesions, n (\%) & $306(32.4)$ & $\begin{array}{l}435 / 1,023 \\
(42.5)\end{array}$ & 0.21 & $290(30.7)$ & $\begin{array}{l}146 / 376 \\
(38.7)\end{array}$ & 0.17 & $294(31.1)$ & $48 / 90(53.3)$ & 0.46 \\
\hline \multicolumn{10}{|c|}{ Panel B: NTZ, DMF, and TERI vs CLARITY study } \\
\hline & $\begin{array}{l}\text { CLARITY } \\
(n=945)\end{array}$ & NTZ (n = 149) & $\begin{array}{l}\text { Standardized mean } \\
\text { difference NTZ vs } \\
\text { CLARITY }\end{array}$ & $\begin{array}{l}\text { CLARITY } \\
(\mathrm{n}=945)\end{array}$ & $\begin{array}{l}\text { DMF } \\
(n=295)\end{array}$ & $\begin{array}{l}\text { Standardized mean } \\
\text { difference DMF vs } \\
\text { CLARITY }\end{array}$ & $\begin{array}{l}\text { CLARITY } \\
(\mathrm{n}=945)\end{array}$ & TERI $(\mathbf{n}=77)$ & $\begin{array}{l}\text { Standardized mean } \\
\text { difference TERI vs } \\
\text { CLARITY }\end{array}$ \\
\hline Age, y, mean (SD) & $37.9(10.4)$ & 36.6 (10.9) & 0.12 & $38.3(10.3)$ & $38.1(10.2)$ & 0.015 & $39.1(10.4)$ & $39.3(11.8)$ & 0.019 \\
\hline Females, n (\%) & $609(64.4)$ & $84(56.4)$ & 0.17 & $617(65.3)$ & $197(66.8)$ & 0.03 & $614(65)$ & 45 (58.4) & 0.13 \\
\hline $\begin{array}{l}\text { EDSS score, mean (SD); } \\
\text { median (IQR) }\end{array}$ & $\begin{array}{l}2.87(1.28) ; 3 \\
(2-4)\end{array}$ & $\begin{array}{l}2.74(1.10) ; 2.5 \\
(2-3.5)\end{array}$ & 0.10 & $\begin{array}{l}2.68(1.30) \\
2.5(1.5-3.5)\end{array}$ & $\begin{array}{l}2.38(1.23) \\
2.5(1.5-3)\end{array}$ & 0.23 & $\begin{array}{l}2.87(1.28) ; 3 \\
(2-4)\end{array}$ & $\begin{array}{l}2.56(1.34) ; 2 \\
(1.5-3.5)\end{array}$ & 0.24 \\
\hline $\begin{array}{l}\text { Disease duration, } \\
\text { mean (SD); median } \\
\text { (IQR) }\end{array}$ & $\begin{array}{l}3.87(5.19) \\
1.8(0.5-5.3)\end{array}$ & $\begin{array}{l}3.28(5.10) \\
0.95 \\
(0.17-4.58)\end{array}$ & 0.11 & $\begin{array}{l}3.84(5.12) ; \\
1.79 \\
(0.51-5.5)\end{array}$ & $\begin{array}{l}3.59(5.61) \\
0.76(0.3-4.4)\end{array}$ & 0.045 & $\begin{array}{l}4.23(5.50) ; \\
2.06 \\
(0.57-5.97)\end{array}$ & $\begin{array}{l}3.76(5.88) \\
1.05 \\
(0.54-3.98)\end{array}$ & 0.08 \\
\hline $\begin{array}{l}\text { ARR in previous year, } \\
\text { mean (SD) }\end{array}$ & $1.36(0.61)$ & $1.42(0.66)$ & 0.089 & $1.32(0.57)$ & $1.29(0.53)$ & 0.068 & $1.33(0.58)$ & $1.32(0.57)$ & 0.017 \\
\hline Active lesions, n (\%) & 299 (31.7) & $89 / 128(69.5)$ & 0.82 & $293(31)$ & $\begin{array}{l}134 / 276 \\
(48.6)\end{array}$ & 0.36 & $287(30.4)$ & 19/72 (26.4) & 0.088 \\
\hline
\end{tabular}

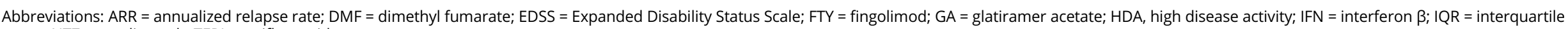
range; NTZ = natalizumab; TERI = teriflunomide. 
Table 2 ARR after IPW adjustment in all the analyzed treatment groups

\begin{tabular}{|c|c|c|c|c|c|c|}
\hline & \multicolumn{3}{|c|}{ IPW clinical variables } & \multicolumn{3}{|c|}{ IPW clinical + MRI variables } \\
\hline & \multirow[b]{2}{*}{$\operatorname{ARR}(95 \% \mathrm{Cl})$} & \multicolumn{2}{|l|}{ ARR ratio $(95 \% \mathrm{Cl})$} & \multirow[b]{2}{*}{ ARR $(95 \% \mathrm{Cl})$} & \multicolumn{2}{|l|}{ ARR ratio $(95 \% \mathrm{Cl})$} \\
\hline & & IFN vs placebo & Cladribine vs IFN & & IFN vs placebo & Cladribine vs IFN \\
\hline Placebo & $0.321(0.275-0.367)$ & $0.76(0.64-0.91) ; p=0.002$ & $0.48(0.41-0.57) ; p<0.001$ & $0.319(0.273-0.365)$ & $0.79(0.66-0.95) ; p=0.011$ & $0.46(0.38-0.55) ; p<0.001$ \\
\hline Cladribine & $0.118(0.101-0.134)$ & & & $0.116(0.099-0.132)$ & & \\
\hline IFN & $0.246(0.222-0.269)$ & & & $0.252(0.226-0.279)$ & & \\
\hline & & GA vs placebo & Cladribine vs GA & & GA vs placebo & Cladribine vs GA \\
\hline Placebo & $0.318(0.254-0.382)$ & $0.78(0.57-1.08) ; p=0.13$ & $0.49(0.36-0.68) ; p<0.001$ & $0.318(0.254-0.383)$ & $0.79(0.57-1.09) ; p=0.14$ & $0.49(0.36-0.68) ; p<0.001$ \\
\hline Cladribine & $0.123(0.099-0.147)$ & & & $0.122(0.098-0.147)$ & & \\
\hline GA & $0.249(0.187-0.311)$ & & & $0.250(0.187-0.313)$ & & \\
\hline & & FTY vs placebo & Cladribine vs FTY & & FTY vs placebo & Cladribine vs FTY \\
\hline Placebo & $0.320(0.257-0.383)$ & $0.54(0.32-0.89) ; p=0.016$ & $0.74(0.45-1.22) ; p=0.24$ & $0.321(0.257-0.385)$ & $0.47(0.28-0.79) ; p=0.005$ & $0.84(0.50-1.41) ; p=0.51$ \\
\hline Cladribine & $0.127(0.103-0.150)$ & & & $0.127(0.103-0.150)$ & & \\
\hline FTY & $0.171(0.091-0.252)$ & & & $0.151(0.078-0.223)$ & & \\
\hline & & NTZ vs placebo & Cladribine vs NTZ & & NTZ vs placebo & Cladribine vs NTZ \\
\hline Placebo & $0.326(0.261-0.391)$ & $0.18(0.10-0.34) ; p<0.001$ & $2.13(1.17-3.88) ; p=0.014$ & $0.329(0.265-0.394)$ & $0.17(0.09-0.32) ; p<0.001$ & $2.28(1.23-4.24) ; p=0.009$ \\
\hline Cladribine & $0.128(0.104-0.152)$ & & & $0.128(0.104-0.152)$ & & \\
\hline NTZ & $0.060(0.026-0.094)$ & & & $0.056(0.023-0.089)$ & & \\
\hline & & DMF vs placebo & Cladribine vs DMF & & DMF vs placebo & Cladribine vs DMF \\
\hline Placebo & $0.312(0.246-0.377)$ & $0.65(0.44-0.97) ; p=0.036$ & $0.60(0.41-0.89) ; p=0.001$ & $0.322(0.256-0.387)$ & $0.64(0.43-0.94) ; p=0.024$ & $0.63(0.43-0.93) ; p=0.02$ \\
\hline Cladribine & $0.123(0.099-0.147)$ & & & $0.129(0.104-0.154)$ & & \\
\hline DMF & $0.204(0.135-0.272)$ & & & $0.204(0.136-0.273)$ & & \\
\hline
\end{tabular}

Abbreviations: $A R R=$ annualized relapse rate; DMF = dimethyl fumarate; FTY = fingolimod; GA = glatiramer acetate; IFN = interferon $\beta$; IPW = inverse probability weighting; NTZ = natalizumab. Results are presented after IPW adjustment with clinical variables (left columns) and with clinical variable + MRI variables (right columns). 

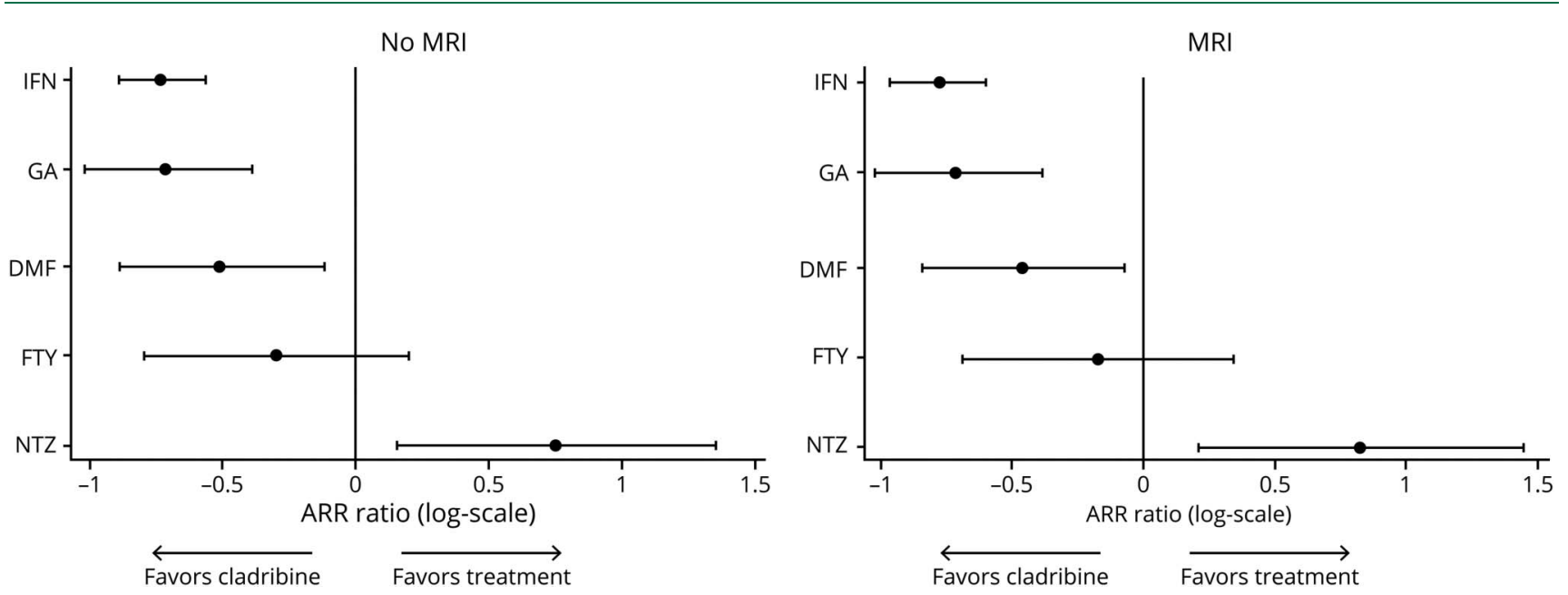

$A R R=$ annualized relapse rate; DMF = dimethyl fumarate; FTY = fingolimod; GA = glatiramer acetate; IFN = interferon $\beta ; N T Z=$ natalizumab.

$2.13(p=0.014)$ (table 2). Cladribine tablets compared with TERI was not analyzed because the TERI arm was too small $(n=77)$ to draw meaningful conclusions. The treatment effects vs placebo were close to those observed in randomized controlled trials and estimated in previous network meta-analyses (table e-9 and figure e-2, links.lww.com/NXI/A298) ${ }^{17-19}$ with largely overlapping CIs for all the drugs. In this study, NTZ showed a reduction in the ARR vs placebo of $82 \%$ (with very large CIs) - higher than that observed in the AFFIRM study $(\mathrm{ARR}$ ratio vs placebo $=68 \%)$ and reestimated in the network meta-analyses, but with overlapping CIs. Similar results were obtained for the analysis including baseline MRI activity in the PS calculation on the subgroup of patients with available MRI information at baseline (table 2, second column). Forest plots for these 2 analyses are presented in figure 1 . Similar results were obtained when considering the 2 different doses of cladribine tablets separately (table e-10).

Our results of the effects of cladribine tablets vs other drugs on ARR were compared with those reported by a previous network meta-analysis (NMA) (figure e-3, links.lww.com/NXI/ A298).$^{20}$ All the cladribine effects vs the other DMDs were within the CIs of those estimated in the NMA. ${ }^{20}$

\section{Disability progression}

The HRs for comparisons of disability progression are reported in table 3 and displayed in figure e-4 (links.lww.com/NXI/ A298). A small proportion of patients had missing data on follow-up EDSS. Excluded patients in each group were 40 (3.42\%) for IFN; 23 (5.72\%) for GA; 5 (4.4\%) for FTY; 15 (10\%) for NTZ; and 33 (11.2\%) for DMF. A significant difference in favor of cladribine tablets on time to disability progression was observed only for GA $(-36 \%$; $p=0.045)$.

The survival curves for progression-free probability of each treatment vs cladribine tablets $3.5 \mathrm{mg} / \mathrm{kg}$ are shown in figure e-5 (links.lww.com/NXI/A298), whereas the HRs for comparisons of disability progression, considering the 2 different doses of cladribine tablets separately, are reported in table e- 11 .

Table 3 Risk of 24-week disability progression of cladribine vs other drugs

\begin{tabular}{|c|c|c|}
\hline & $\begin{array}{l}\text { IPW clinical } \\
\text { variables }\end{array}$ & $\begin{array}{l}\text { IPW clinical + MRI } \\
\text { variables }\end{array}$ \\
\hline & HR $(95 \% \mathrm{Cl})$ & $\mathrm{HR}(95 \% \mathrm{Cl})$ \\
\hline $\begin{array}{l}\text { IFN }(n=1,128) \text { vs } \\
\text { placebo }\end{array}$ & $\begin{array}{l}0.72(0.55-0.94) \\
p=0.017\end{array}$ & $\begin{array}{l}0.75(0.57-0.99) \\
p=0.046\end{array}$ \\
\hline Cladribine vs IFN & $\begin{array}{l}0.86(0.68-1.09) \\
p=0.22\end{array}$ & $\begin{array}{l}0.81(0.62-1.05) \\
p=0.11\end{array}$ \\
\hline $\begin{array}{l}\text { GA }(n=379) \text { vs } \\
\text { placebo }\end{array}$ & $\begin{array}{l}0.93(0.58-1.47) \\
p=0.74\end{array}$ & $\begin{array}{l}1.00(0.63-1.59) \\
p=0.99\end{array}$ \\
\hline Cladribine vs GA & $\begin{array}{l}0.64(0.41-0.99) \\
p=0.045\end{array}$ & $\begin{array}{l}0.58(0.38-0.90) \\
p=0.015\end{array}$ \\
\hline $\begin{array}{l}\text { FTY }(n=108) \text { vs } \\
\text { placebo }\end{array}$ & $\begin{array}{l}0.61(0.30-1.27) \\
p=0.19\end{array}$ & $\begin{array}{l}0.65(0.32-1.30) \\
p=0.23\end{array}$ \\
\hline Cladribine vs FTY & $\begin{array}{l}0.89(0.44-1.83) \\
p=0.76\end{array}$ & $\begin{array}{l}0.84(0.42-1.67) \\
p=0.62\end{array}$ \\
\hline $\begin{array}{l}\text { NTZ }(n=134) \text { vs } \\
\text { placebo }\end{array}$ & $\begin{array}{l}0.45(0.22-0.92) \\
p=0.028\end{array}$ & $\begin{array}{l}0.35(0.16-0.78) \\
p=0.01\end{array}$ \\
\hline Cladribine vs NTZ & $\begin{array}{l}1.20(0.59-2.42) \\
p=0.61\end{array}$ & $\begin{array}{l}1.51(0.69-3.33) \\
p=0.31\end{array}$ \\
\hline $\begin{array}{l}\text { DMF }(n=262) \text { vs } \\
\text { placebo }\end{array}$ & $\begin{array}{l}0.54(0.29-1.00) \\
p=0.051\end{array}$ & $\begin{array}{l}0.68(0.38-1.19) \\
p=0.18\end{array}$ \\
\hline Cladribine vs DMF & $\begin{array}{l}1.07(0.59-1.94) \\
p=0.83\end{array}$ & $\begin{array}{l}0.80(0.46-1.39) \\
p=0.43\end{array}$ \\
\hline
\end{tabular}

Abbreviations: $\mathrm{DMF}=$ dimethyl fumarate; $\mathrm{FTY}=$ fingolimod; $\mathrm{GA}=$ glatiramer acetate; $\mathrm{HR}=$ hazard ratio; IFN = interferon $\beta ; \mathrm{IPW}=$ inverse probability weighting; NTZ = natalizumab. 
Figure 2 Relapse rate ratio of cladribine vs each other treatment according to HDA subgroups

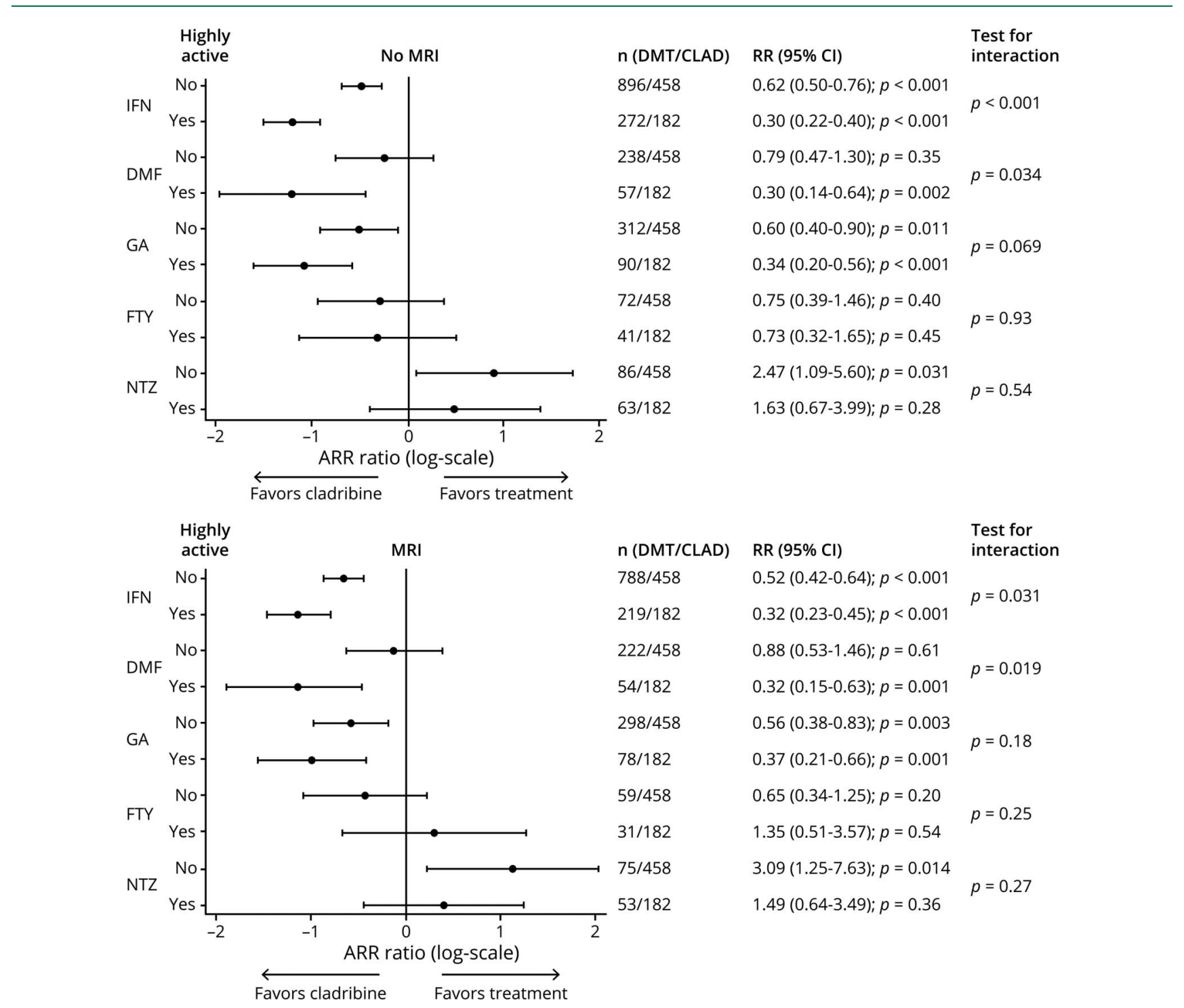

$A R R=$ annualized relapse rate; $C L A D=$ cladribine; $D M D=$ disease-modifying drug; $D M F=$ dimethyl fumarate; $F T Y=$ fingolimod; GA = glatiramer acetate; $H D A$, high disease activity; IFN = interferon $\beta$; NTZ = natalizumab; RR = relapse ratio.

\section{Subgroup analyses}

The effect of cladribine tablets vs other drugs was tested in subgroups defined according to baseline disease activity. The weighted baseline characteristics for each treatment by subgroup (HDA vs non-HDA) are presented in tables e-12 and e-13 (links.lww.com/NXI/A298). The same characteristics are reported in tables e-14 to e-18 with the 3 arms of CLARITY presented separately. Results on ARR are shown in figure 2 . The effect of cladribine tablets was generally amplified in the HDA subgroup and the same was true for cladribine $3.5 \mathrm{mg}$ alone (table e-19). The subgroup analysis run on time to disability progression is presented in tables e-20 and e- 21 . The same trend for a higher efficacy of cladribine tablets is observable in the HDA subgroup.

\section{Sensitivity analyses}

\section{PS matching 1:1}

Baseline characteristics of patients after 1:1 PS matching are reported in table e-22 (links.lww.com/NXI/A298). A good balance with standardized differences $<0.10$ for almost all characteristics and treatments was observed. The ARR ratio between cladribine tablets and single treatment arms after 1:1 PS matching (table e-23) confirmed in general the results observed with the IPW approach.

\section{PS matching 3:1}

The characteristics of matched samples after up to 3:1 PS matching are reported in table e-24 (links.lww.com/NXI/ A298). Here also a good balance was observed between the 
compared groups. The ARR ratio between cladribine tablets and single treatment arms after 3:1 PS matching (table e-25) confirmed the results observed with the IPW approach.

\section{Stratification of IFN arms}

The IPW-weighted baseline characteristics of the 3 IFN arms split are reported in table e-26 (links.lww.com/NXI/A298). Good balance with standardized differences $<0.10$ was observed for almost all characteristics across the 3 arms compared with CLARITY. The weighted ARR ratio (table e-27, links.lww. com/NXI/A298) showed a higher effect of cladribine tablets in IFN-1b and IFN-1a SC compared with IFN-1a IM.

\section{Discussion}

This study presents a novel approach, matching individual patient data from the CLARITY randomized controlled phase III trial with those included in a large multicenter observational study in newly diagnosed patients. The presence of the placebo arm from CLARITY allowed us to compare, as a first step, the effectiveness of each drug from the observational study vs placebo with the effect reported in randomized clinical trials. The effect of each treatment vs placebo was close to that observed in the clinical trials except for NTZ, where a larger effect in the drug vs placebo was seen (ARR ratio $82 \%$ vs $68 \%$ reported in the AFFIRM trial ${ }^{21}$ ), even if the large CIs of the estimate obtained in this study limit the interpretation of such result.

The results from comparative effectiveness showed a superiority of cladribine tablets vs IFN, GA, and DMF on the relapse rate in the first 2 years. No significant differences were observed with FTY, whereas NTZ was shown to be superior.

Similar results were observed in a previous observational study ${ }^{22}$ on comparative effectiveness of cladribine conducted in a cohort of patients from the MSBase International Registry. A small cohort of patients treated with cladribine vs FTY, NTZ, and IFN showed a superiority of cladribine vs IFN and a superiority of NTZ on cladribine on hazard of first relapse. On the same outcome, no significant differences between cladribine and FTY were detected. No comparisons vs GA or DMF were performed.

A recent $\mathrm{NMA}^{20}$ compared the effects of various DMDs on ARR and confirmed disability progression in active and highly active RRMS, including 41 studies. Cladribine was ranked in fourth position on a scale of efficacy for ARR reduction after alemtuzumab, NTZ, and ocrelizumab. In the same NMA, a significant reduction of ARR with cladribine, estimated around $40 \%$ vs GA and up to $48 \%$ vs IFN, was reported and was close to that observed in our study. When compared with DMF, the ARR reduction due to cladribine was not significant and lower than that observed in our study (22\%; 95\% CI $43 \%-7 \%)$ in NMA vs $36 \%$ in our study; our data are therefore consistent with those reported in NMA). The ARR under cladribine was comparable to FTY and higher than the ARR under NTZ, even if the difference was not significant.
In the $\mathrm{NMA}^{20}{ }^{20}$ cladribine was statistically similar to the other DMDs on confirmed disability progression. In our study, the superiority of cladribine was detected only vs GA.

Cladribine is approved and indicated mainly for the treatment of patients with highly active RRMS. Having individual patient data, we were able to perform a subgroup analysis, which indicated a higher efficacy of cladribine vs other DMDs in patients with HDA, with ARR reduction close to $70 \%$ vs IFN, GA, and DMF in this specific subgroup of patients.

\section{Study limitations}

This study carries all the well-known limitations of nonrandomized comparisons, with the advantage of a placebo arm giving a benchmark for comparisons. ${ }^{23}$ In addition, the sample size for all the comparisons on disability progression was low, giving estimates with large CIs. To mitigate the potential bias due to the lack of randomization, we applied an IPW in the main analysis as well as several sensitivity analyses with different matching algorithms.

With our comparative results, based on a wide national database (i-MuST) and the CLARITY data set, we simulated a scenario representing the complexity of management of patients with MS, which confirms the effectiveness of cladribine tablets in treating RRMS. Our approach let us overcome the lack of direct head-to-head comparisons of cladribine tablets to other common DMDs. We confirmed the superiority of cladribine tablets in reducing relapse rate, during the first 2 years, compared with its major competitors, such as IFN, GA, and DMF; NTZ data were still superior as given in the results. Finally, having individual patient data, we were able to show the higher efficacy of cladribine in the subgroup of patients with HDA.

\section{Study funding}

This study was sponsored by Merck Serono S.p.A., Rome, Italy; an affiliate of Merck KGaA, Darmstadt, Germany.

\section{Disclosure}

A. Signori, F. Saccà, R. Lanzillo, G.T. Maniscalco, E. Signoriello, A. M. Repice, P. Annovazzi, D. Baroncini, M. Clerico, E. Binello, R. Cerqua, G. Mataluni, P. Perini, S. Bonavita, L. Lavorgna, I. R. Zarbo, A. Laroni, L. Pareja-Gutierrez, S. La Gioia, B. Frigeni, V. Barcella, J. Frau, E. Cocco, G. Fenu, V. T. Clerici, A. Sartori, S. Rasia, C. Cordioli, M. L. Stromillo, A. Di Sapio, S. Pontecorvo, R. Grasso, S. Barone, C. Barrilà, C. V. Russo, S. Esposito, D. Ippolito, and D. Landi have nothing to disclose. A. Visconti is an employee at Merck Serono, Italy. M. P. Sormani received consulting fees from Merck KGaA, Novartis, Biogen, Roche, Sanofi, Teva, Celgene, MedDay, GeNeuro, and Immunic. Go to Neurology.org/NN for full disclosures.

\section{Publication history}

Received by Neurology: Neuroimmunology \& Neuroinflammation May 27, 2020. Accepted in final form July 16, 2020. 
Appendix Authors

\begin{tabular}{|c|c|c|}
\hline Name & Location & Contribution \\
\hline $\begin{array}{l}\text { Alessio Signori, } \\
\text { PhD }\end{array}$ & University of Genoa & $\begin{array}{l}\text { Designed and } \\
\text { conceptualized } \\
\text { the study; analyzed the } \\
\text { data; and drafted the } \\
\text { manuscript for } \\
\text { intellectual content }\end{array}$ \\
\hline $\begin{array}{l}\text { Francesco Saccà, } \\
\text { MD }\end{array}$ & $\begin{array}{l}\text { University Federico II } \\
\text { Naples }\end{array}$ & $\begin{array}{l}\text { Major role in the } \\
\text { acquisition of data }\end{array}$ \\
\hline $\begin{array}{l}\text { Roberta Lanzillo, } \\
\text { MD, PhD }\end{array}$ & $\begin{array}{l}\text { University Federico II } \\
\text { Naples }\end{array}$ & $\begin{array}{l}\text { Major role in the } \\
\text { acquisition of data }\end{array}$ \\
\hline $\begin{array}{l}\text { Giorgia Teresa } \\
\text { Maniscalco, MD }\end{array}$ & $\begin{array}{l}\text { AORN Cardarelli } \\
\text { Naples }\end{array}$ & $\begin{array}{l}\text { Major role in the } \\
\text { acquisition of data }\end{array}$ \\
\hline $\begin{array}{l}\text { Elisabetta } \\
\text { Signoriello, MD, } \\
\text { PhD }\end{array}$ & $\begin{array}{l}\text { University Luigi } \\
\text { Vanvitelli, Naples }\end{array}$ & $\begin{array}{l}\text { Major role in the } \\
\text { acquisition of data }\end{array}$ \\
\hline $\begin{array}{l}\text { Anna Maria } \\
\text { Repice, MD }\end{array}$ & $\begin{array}{l}\text { Careggi University } \\
\text { Hospital, Florence }\end{array}$ & $\begin{array}{l}\text { Major role in the } \\
\text { acquisition of data }\end{array}$ \\
\hline $\begin{array}{l}\text { Pietro Annovazzi, } \\
\text { MD } \\
\text { Damiano } \\
\text { Baroncini, MD }\end{array}$ & $\begin{array}{l}\text { ASST Valle Olona, PO } \\
\text { Gallarate }\end{array}$ & $\begin{array}{l}\text { Major role in the } \\
\text { acquisition of data }\end{array}$ \\
\hline $\begin{array}{l}\text { Marinella Clerico, } \\
\text { MD, PhD }\end{array}$ & University of Turin & $\begin{array}{l}\text { Major role in the } \\
\text { acquisition of data }\end{array}$ \\
\hline $\begin{array}{l}\text { Eleonora Binello, } \\
\text { MD }\end{array}$ & Turin & $\begin{array}{l}\text { Major role in the } \\
\text { acquisition of data }\end{array}$ \\
\hline $\begin{array}{l}\text { Raffaella Cerqua, } \\
\text { MD }\end{array}$ & $\begin{array}{l}\text { Marche Polytechnic } \\
\text { University, Ancona }\end{array}$ & $\begin{array}{l}\text { Major role in the } \\
\text { acquisition of data }\end{array}$ \\
\hline $\begin{array}{l}\text { Giorgia Mataluni, } \\
\text { MD, PhD }\end{array}$ & $\begin{array}{l}\text { Policlinic Tor Vergata, } \\
\text { Rome }\end{array}$ & $\begin{array}{l}\text { Major role in the } \\
\text { acquisition of data }\end{array}$ \\
\hline $\begin{array}{l}\text { Paola Perini, MD, } \\
\text { PhD }\end{array}$ & University of Padua & $\begin{array}{l}\text { Major role in the } \\
\text { acquisition of data }\end{array}$ \\
\hline $\begin{array}{l}\text { Simona Bonavita, } \\
\text { MD }\end{array}$ & $\begin{array}{l}\text { University Luigi } \\
\text { Vanvitelli }\end{array}$ & $\begin{array}{l}\text { Major role in the } \\
\text { acquisition of data }\end{array}$ \\
\hline $\begin{array}{l}\text { Luigi Lavorgna, } \\
\text { MD, PhD }\end{array}$ & $\begin{array}{l}\text { University Luigi } \\
\text { Vanvitelli }\end{array}$ & $\begin{array}{l}\text { Major role in the } \\
\text { acquisition of data }\end{array}$ \\
\hline $\begin{array}{l}\text { Ignazio Roberto } \\
\text { Zarbo, PhD }\end{array}$ & University of Sassari & $\begin{array}{l}\text { Major role in the } \\
\text { acquisition of data }\end{array}$ \\
\hline $\begin{array}{l}\text { Alice Laroni, MD, } \\
\text { PhD }\end{array}$ & University of Genoa & $\begin{array}{l}\text { Major role in the } \\
\text { acquisition of data }\end{array}$ \\
\hline $\begin{array}{l}\text { Lorena Pareja- } \\
\text { Gutierrez, MD }\end{array}$ & IRCCS Besta Milan & $\begin{array}{l}\text { Major role in the } \\
\text { acquisition of data }\end{array}$ \\
\hline Sara La Gioia, MD & $\begin{array}{l}\text { Centro SM Papa } \\
\text { Giovanni XXIII } \\
\text { Bergamo }\end{array}$ & $\begin{array}{l}\text { Major role in the } \\
\text { acquisition of data }\end{array}$ \\
\hline $\begin{array}{l}\text { Barbara Frigeni, } \\
\text { MD }\end{array}$ & $\begin{array}{l}\text { Centro SM Papa } \\
\text { Giovanni XXIII } \\
\text { Bergamo }\end{array}$ & $\begin{array}{l}\text { Major role in the } \\
\text { acquisition of data }\end{array}$ \\
\hline $\begin{array}{l}\text { Valeria Barcella, } \\
\text { MD }\end{array}$ & $\begin{array}{l}\text { Centro SM Papa } \\
\text { Giovanni XXIII } \\
\text { Bergamo }\end{array}$ & $\begin{array}{l}\text { Major role in the } \\
\text { acquisition of data }\end{array}$ \\
\hline Jessica Frau, MD & University of Cagliari & $\begin{array}{l}\text { Major role in the } \\
\text { acquisition of data }\end{array}$ \\
\hline $\begin{array}{l}\text { Eleonora Cocco, } \\
\text { MD }\end{array}$ & University of Cagliari & $\begin{array}{l}\text { Major role in the } \\
\text { acquisition of data }\end{array}$ \\
\hline
\end{tabular}

Appendix (continued)

\begin{tabular}{|c|c|c|}
\hline Name & Location & Contribution \\
\hline $\begin{array}{l}\text { Giuseppe Fenu, } \\
\text { MD, PhD }\end{array}$ & University of Cagliari & $\begin{array}{l}\text { Major role in the } \\
\text { acquisition of data }\end{array}$ \\
\hline $\begin{array}{l}\text { Valentina Torri } \\
\text { Clerici, MD }\end{array}$ & IRCCS Besta Milan & $\begin{array}{l}\text { Major role in the } \\
\text { acquisition of data }\end{array}$ \\
\hline $\begin{array}{l}\text { Arianna Sartori, } \\
\text { MD }\end{array}$ & University of Trieste & $\begin{array}{l}\text { Major role in the } \\
\text { acquisition of data }\end{array}$ \\
\hline Sarah Rasia, MD & Spedali Civili Brescia & $\begin{array}{l}\text { Major role in the } \\
\text { acquisition of data }\end{array}$ \\
\hline $\begin{array}{l}\text { Cinzia Cordioli, } \\
\text { MD }\end{array}$ & Spedali Civili Brescia & $\begin{array}{l}\text { Major role in the } \\
\text { acquisition of data }\end{array}$ \\
\hline $\begin{array}{l}\text { Maria Laura } \\
\text { Stromillo, MD, } \\
\text { PhD }\end{array}$ & University of Siena & $\begin{array}{l}\text { Major role in the } \\
\text { acquisition of data }\end{array}$ \\
\hline $\begin{array}{l}\text { Alessia Di Sapio, } \\
\text { MD }\end{array}$ & $\begin{array}{l}\text { Regina Montis } \\
\text { Hospital Mondovi }\end{array}$ & $\begin{array}{l}\text { Major role in the } \\
\text { acquisition of data }\end{array}$ \\
\hline $\begin{array}{l}\text { Simona } \\
\text { Pontecorvo, MD, } \\
\text { PhD }\end{array}$ & $\begin{array}{l}\text { Sapienza University, } \\
\text { Rome }\end{array}$ & $\begin{array}{l}\text { Major role in the } \\
\text { acquisition of data }\end{array}$ \\
\hline $\begin{array}{l}\text { Roberta Grasso, } \\
\text { MD }\end{array}$ & $\begin{array}{l}\text { Neurologia } \\
\text { Universitaria Foggia }\end{array}$ & $\begin{array}{l}\text { Major role in the } \\
\text { acquisition of data }\end{array}$ \\
\hline $\begin{array}{l}\text { Stefania Barone, } \\
\text { MD }\end{array}$ & $\begin{array}{l}\text { University of } \\
\text { Catanzaro }\end{array}$ & $\begin{array}{l}\text { Major role in the } \\
\text { acquisition of data }\end{array}$ \\
\hline $\begin{array}{l}\text { Caterina Barrilà, } \\
\text { MD }\end{array}$ & $\begin{array}{l}\text { Valduce Hospital } \\
\text { Como }\end{array}$ & $\begin{array}{l}\text { Major role in the } \\
\text { acquisition of data }\end{array}$ \\
\hline $\begin{array}{l}\text { Cinzia Valeria } \\
\text { Russo, MD }\end{array}$ & $\begin{array}{l}\text { University Federico II } \\
\text { Naples }\end{array}$ & $\begin{array}{l}\text { Major role in the } \\
\text { acquisition of data }\end{array}$ \\
\hline $\begin{array}{l}\text { Sabrina Esposito, } \\
\text { MD }\end{array}$ & $\begin{array}{l}\text { University Luigi } \\
\text { Vanvitelli Naples }\end{array}$ & $\begin{array}{l}\text { Major role in the } \\
\text { acquisition of data }\end{array}$ \\
\hline $\begin{array}{l}\text { Domenico } \\
\text { Ippolito, MD }\end{array}$ & $\begin{array}{l}\text { University Luigi } \\
\text { Vanvitelli Naples }\end{array}$ & $\begin{array}{l}\text { Major role in the } \\
\text { acquisition of data }\end{array}$ \\
\hline $\begin{array}{l}\text { Doriana Landi, } \\
\text { MD, PhD }\end{array}$ & $\begin{array}{l}\text { Policlinic Tor Vergata, } \\
\text { Rome }\end{array}$ & $\begin{array}{l}\text { Major role in the } \\
\text { acquisition of data }\end{array}$ \\
\hline $\begin{array}{l}\text { Andrea Visconti, } \\
\text { MD }\end{array}$ & $\begin{array}{l}\text { Merck Serono S.p.A., } \\
\text { Rome }\end{array}$ & $\begin{array}{l}\text { Drafted the manuscript } \\
\text { for intellectual content }\end{array}$ \\
\hline $\begin{array}{l}\text { Maria Pia } \\
\text { Sormani, PhD }\end{array}$ & University of Genoa & $\begin{array}{l}\text { Designed and } \\
\text { conceptualized } \\
\text { the study; analyzed the } \\
\text { data; drafted the } \\
\text { manuscript } \\
\text { for intellectual content; } \\
\text { and supervised the } \\
\text { study }\end{array}$ \\
\hline
\end{tabular}

\section{References}

1. Thompson AJ, Baranzini SE, Geurts J, et al. Multiple sclerosis. Lancet 2018;391 1622-1636.

2. Baker D, Pryce G, Herrod SS, Schmierer K. Potential mechanisms of action related to the efficacy and safety of cladribine. Mult Scler Relat Disord 2019;30:176-186.

3. Giovannoni G, Comi G, Cook S, et al. CLARITY Study Group. A placebo-controlled trial of oral cladribine for relapsing multiple sclerosis. N Engl J Med 2010;362: 416-426.

4. Giovannoni G, Soelberg Sorensen P, Cook S, et al. Safety and efficacy of cladribine tablets in patients with relapsing-remitting multiple sclerosis: results from the randomized extension trial of the CLARITY study. Mult Scler 2018;24:1594-1604.

5. Saccà F, Lanzillo R, Signori A, et al. Determinants of therapy switch in multiple sclerosis treatment-naive patients: a real-life study. Mult Scler 2019;25:1263-1272. 
6. McDonald WI, Compston A, Edan G, et al. Recommended diagnostic criteria for multiple sclerosis: guidelines from the International Panel on the diagnosis of multiple sclerosis. Ann Neurol 2001;50:121-127.

7. Polman $\mathrm{CH}$, Reingold SC, Banwell B, et al. Diagnostic criteria for multiple sclerosis: 2010 revisions to the McDonald criteria. Ann Neurol 2011;69:292-302.

8. Kurtzke JF. Rating neurologic impairment in multiple sclerosis: an Expanded Disability Status Scale (EDSS). Neurology 1983;33:1444-1452.

9. Cohen J. Statistical Power Analysis for the Behavioral Sciences. 2nd ed. Hillsdale, NJ: Lawrence Erlbaum Associates Publishers; 1988.

10. Normand ST, Landrum MB, Guadagnoli E, et al. Validating recommendations for coronary angiography following acute myocardial infarction in the elderly: a matched analysis using propensity scores. J Clin Epidemiol 2001;54:387-398.

11. Rosenbaum PR, Rubin DB. The central role of the propensity score in observational studies for causal effects. Biometrika 1983;70:41-55.

12. Rosenbaum PR, Rubin DB. Reducing bias in observational studies using subclassification on the propensity score. J Am Stat Assoc 1984;79:516-524.

13. Austin PC. An introduction to propensity-score methods for reducing the effects of confounding in observational studies. Multivariate Behav Res 2011;46:399-424.

14. Rosenbaum PR. Model-based direct adjustment. J Am Stat Assoc 1987;82:387-394.

15. Austin PC, Stuart EA. Moving towards best practice when using inverse probability of treatment weighting (IPTW) using the propensity score to estimate causal treatment effects in observational studies. Stat Med 2015;34:3661-3679.
16. Cole SR, Hernán MA. Constructing inverse probability weights for marginal structural models. Am J Epidemiol 2008;168:656-664.

17. Lucchetta RC, Tonin FS, Borba HHL, et al. Disease-modifying therapies for relapsingremitting multiple sclerosis: a network meta-analysis. CNS Drugs 2018;32:813-826.

18. Hamidi V, Couto E, Ringerike T, Klemp M. A multiple treatment comparison of eleven disease-modifying drugs used for multiple sclerosis. J Clin Med Res 2018;10: 88-105.

19. Fogarty E, Schmitz S, Tubridy N, Walsh C, Barry M. Comparative efficacy of diseasemodifying therapies for patients with relapsing remitting multiple sclerosis: systematic review and network meta-analysis. Mult Scler Relat Disord 2016;9:23-30.

20. Siddiqui MK, Khurana IS, Budhia $S$, et al. Systematic literature review and network meta-analysis of cladribine tablets versus alternative disease-modifying treatment for relapsing-remitting multiple sclerosis. Curr Med Res Opin 2018; 34:1361-1371.

21. Hutchinson M, Kappos L, Calabresi P, et al. The efficacy of natalizumab in patients with relapsing multiple sclerosis: subgroup analyses of AFFIRM and SENTINEL. J Neurol 2009;256:405-415.

22. Kalincik $\mathrm{T}$, Jokubaitis V, Spelman $\mathrm{T}$, et al. Cladribine versus fingolimod, natalizumab and interferon $\beta$ for multiple sclerosis. Mult Scler 2018;24:1617-1626.

23. Trojano $\mathrm{M}$, Tintore $\mathrm{M}$, Montalban $\mathrm{X}$, et al. Treatment decisions in multiple sclerosis—insights from real-world observational studies. Nat Rev Neurol 2017;13: $105-118$. 


\section{Neurology \\ Neuroimmunology \& Neuroinflammation}

\section{Cladribine vs other drugs in MS: Merging randomized trial with real-life data Alessio Signori, Francesco Saccà, Roberta Lanzillo, et al. \\ Neurol Neuroimmunol Neuroinflamm 2020;7; \\ DOI 10.1212/NXI.0000000000000878}

This information is current as of August 14, 2020

Updated Information \& Services

References

Subspecialty Collections

Permissions \& Licensing

Reprints including high resolution figures, can be found at: http://nn.neurology.org/content/7/6/e878.full.html

This article cites 22 articles, 0 of which you can access for free at: http://nn.neurology.org/content/7/6/e878.full.html\#\#ref-list-1

This article, along with others on similar topics, appears in the following collection(s):

Class III

http://nn.neurology.org//cgi/collection/class_iii

Multiple sclerosis

http://nn.neurology.org//cgi/collection/multiple_sclerosis

Information about reproducing this article in parts (figures,tables) or in its entirety can be found online at:

http://nn.neurology.org/misc/about.xhtml\#permissions

Information about ordering reprints can be found online: http://nn.neurology.org/misc/addir.xhtml\#reprintsus

Neurol Neuroimmunol Neuroinflamm is an official journal of the American Academy of Neurology.

Published since April 2014, it is an open-access, online-only, continuous publication journal. Copyright

Copyright (C) 2020 The Author(s). Published by Wolters Kluwer Health, Inc. on behalf of the American

Academy of Neurology.. All rights reserved. Online ISSN: 2332-7812.

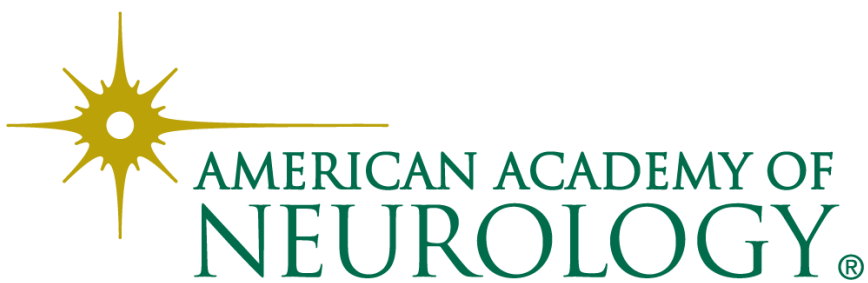

